\title{
Numerical Analysis of Slope Stability Due to Excavation of Diversion Tunnel at Pamukkulu Dam Site
}

\author{
Wakhid Khoiron Nugroho, I Gde Budi Indrawan, and Nugroho Imam Setiawan \\ Department of Geological Engineering, Faculty of Engineering, Universitas Gadjah Mada, Yogyakarta, Indonesia
}

\begin{abstract}
Located in the Takalar Regency of South Sulawesi Province, the Pamukkulu Dam is planned to use a tunnel type as its diversion structure. One of the critical parts of tunnel construction is the stability of portal slopes. This research aimed to estimate the effect of tunnel excavation on the stability of the portal inlet and outlet slopes under static and earthquake loads by using the finite element method. The slope stability analyses were carried out under conditions before and after tunnel excavation. The input parameters used were laboratory test results in the forms of index properties and mechanical properties taken from rock core drilling samples, complete with the rock mass quality parameters based on the Geological Strength Index (GSI) classification. The Mohr-Coulomb failure criterion was used to model the soil strength, while the Generalized Hoek-Brown failure criterion was used to model the rock strength. The results of rock cores analysis using the GSI method showed that the inlet tunnel slope consisted of four types of materials: residual soil, fair quality of basalt lava, good quality of basalt lava, and excellent quality basalt lava. Meanwhile, the outlet portal slope consisted of three types of materials, namely residual soil, good quality basalt lava, and very good quality basalt lava. The calculated horizontal seismic coefficient for the pseudo-static slope stability analysis was 0.0375. The analysis results of slope stability in the Y1 inlet section had a critical Strength Reduction Factor (SRF) value of 2.35 in a condition before the tunnel excavation and a critical SRF value of 2.34 after the tunnel excavation. The Y2 outlet section had a critical SRF value of 13.27 before tunnel excavation and a critical SRF value of 5.55 after the tunnel excavation. The earthquake load application at the Y1 inlet section showed a critical SRF value of 2.05, both before and after the tunnel excavation. The Y2 outlet section showed a critical SRF value of 11.49 before the tunnel excavation and a critical SRF value of 5.54 after the tunnel excavation. The numerical analysis results showed that earthquake load reduced critical SRF values of the slopes. At the Y1 inlet section, the tunnel excavation did not have a significant effect on slope stability. It was demonstrated by an extremely small decrease in a critical SRF value of $0.43 \%$ for a condition without an earthquake load and an unchanged critical SRF in a condition with an earthquake load. At the Y2 outlet section, the tunnel excavation had a more significant effect on the slope stability. It was exhibited by the decrease in the critical SRF value of $58.18 \%$ in the static condition and a decrease in the critical SRF value of $51.78 \%$ in the condition of earthquake load application. However, the slope stability analyses for both sections showed that all design slopes were above the required allowable safety factor value.
\end{abstract}

Keywords: Diversion tunnel · Finite element · GSI · Slope stability · Pamukkulu Dam.

\footnotetext{
${ }^{*}$ Corresponding author: I G. B. INDRAWAN, Department of Geological Engineering, Universitas Gadjah
}

Mada. Jl. Grafika 2 Yogyakarta, Indonesia. E-mail: igbindrawan@ugm.ac.id 


\section{INTRODUCTION}

Located in the Takalar Regency of South Sulawesi Province (Figure 1), the Pamukkulu Dam is planned to use a tunnel type as its diversion structure. The decision to select this type of diversion channel was based on the hilly surrounding morphology with its slope classification as moderate and the consideration of time and cost-effectiveness regarding the construction. One of the critical parts of tunnel construction is the stability of tunnel portal slopes. Balai Besar Wilayah Sungai Pompengan Jeneberang designed the tunnel portal slopes at the $\mathrm{Pa}$ mukkulu Dam to have a $45^{\circ}$ inclination, $5 \mathrm{~m}$ height, and $2 \mathrm{~m}$ length of the individual bench.

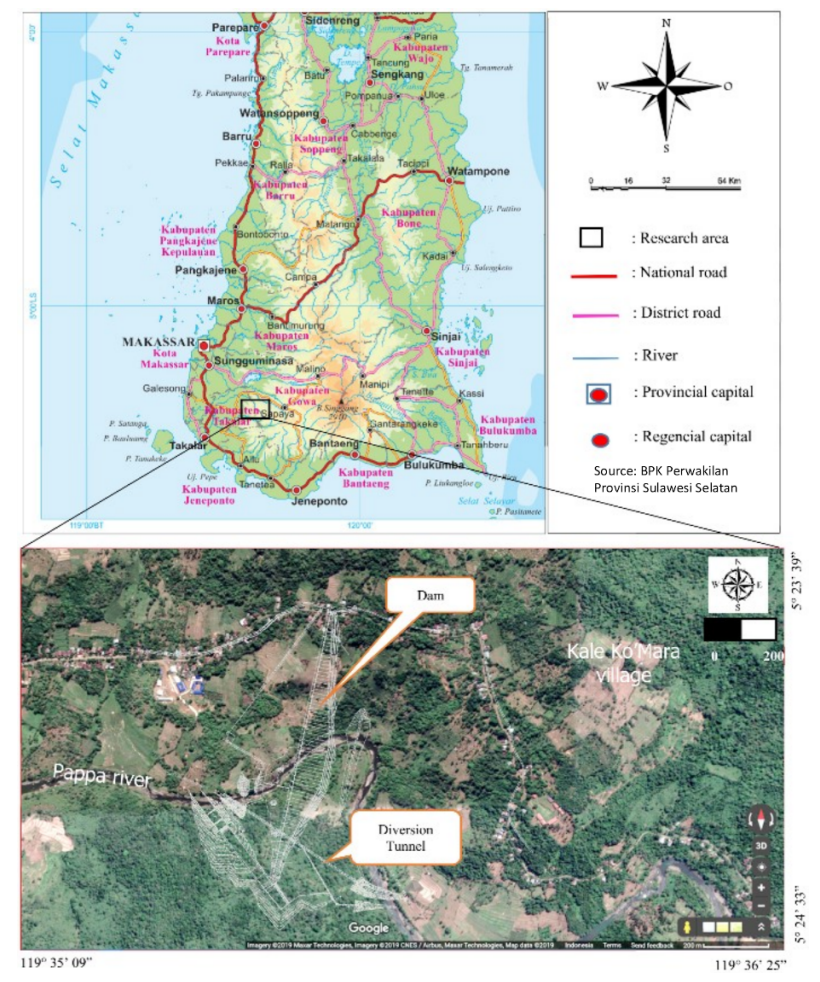

FIGURE 1. Pamukkulu Dam - Takalar Regency of South Sulawesi Province.

This research aimed to estimate the effect of tunnel excavation on the stability of the portal inlet and outlet slopes under static and earthquake loads by using the finite element method. The finite element method has been increasingly applied in slope stability analyses due to its power and flexibility (Hammah et al., 2004).

A numerical evaluation was needed to verify the slope design to be applied in the research area. In addition, the addition of earth- quake loads can also be modeled in the numerical method so that it is expected that the slope stability design will be effectively carried out in the research area.

\section{Geological Setting}

The evaluation of drill cores in this study indicated that the research area comprises two main types of lithologies, namely basalt lava and pyroclastic breccia units. The rock units are members of the Volcanic Rocks of Baturape - Cindako (Tpbv) described in the Regional Geological Map of Ujungpandang, Benteng, and Sinjai, Sulawesi Sheet produced by Sukamto and Supriatna (1982), as shown in Figure 2. According to Nugroho (2020), two normal faults with NW-SE orientations and one dextral strike-slip fault with NE-SW orientation existed on the northern side of the research area. However, the locations of those three faults do not cut the tunnel area and, therefore, were not expected to affect the stability of tunnel portal slopes significantly.

\section{METHOD}

The primary data collection involved evaluations of soil and rock cores obtained from the borehole BT.02, located near the tunnel inlet, and boreholes BH.05 and B.AD5, which were located near the tunnel outlet, as shown in Figure 3. The drill cores were collected by Balai Besar Wilayah Sungai Pompengan Jeneberang. The evaluations of soil and rock cores involved the determination of soil and rock type and engineering properties. Descriptions of rock mass quality are based on GSI (Sivakugan et al., 2013). In addition, the quality of the rock masses consisting of the slopes was determined from the rock cores at the boreholes BT.02 and BH.05 using Equation 1, as proposed by Hoek et al. (2013).

$$
G S I=1.5 \text { Cond }_{89}+\frac{R Q D}{2}
$$

where $\operatorname{JCond}_{89}=$ joint conditions of rock cores as described in Bieniawski (1989); RQD $=$ rock quality designation.

The slope stability analyses were performed at the tunnel inlet and outlet using a finite element-based RS2 v.9.0 software developed by 


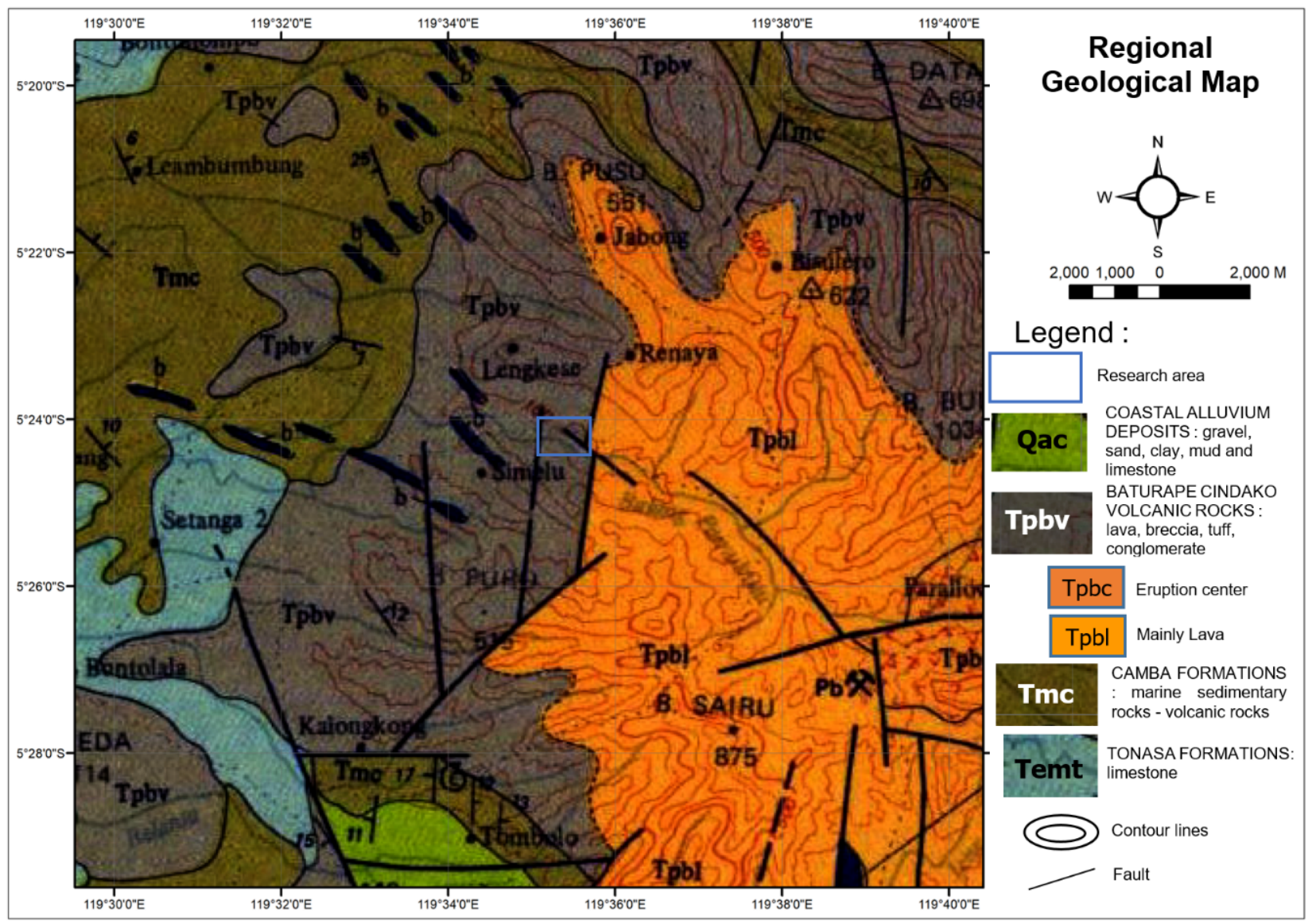

FIGURE 2. Part of Regional Geological Map of Ujungpandang, Benteng, and Sinjai, Sulawesi Sheet (Sukamto and Supriatna, 1982).

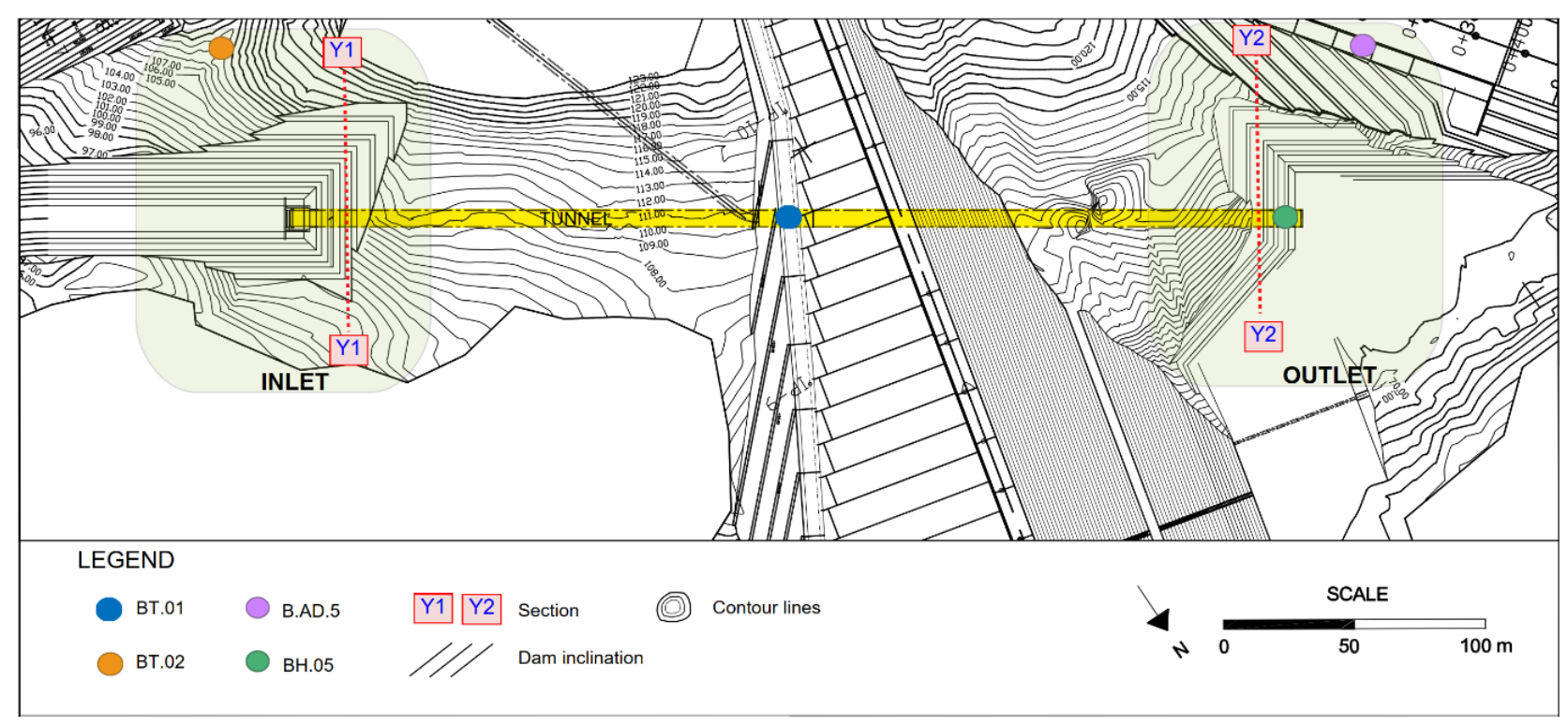

FIGURE 3. Location of tunnel inlet and outlet slopes (BBWS Pompengan-Jeneberang, 2016). 
Rocscience, Inc, 2015. The type of analysis applied in this numerical modeling was a plane strain. The stress analysis used was effective stress, tensile failure reduce shear strength, and joint tension reduce joint stiffness. The mesh type used was a graded mesh with 3noded triangles as the element type. The failure criterion used for the soil was the MohrCoulomb, and that for the rocks was the Generalized Hoek-Brown. Slope stability analysis under earthquake load was carried out using the pseudo-static method following the guidelines of SNI 8460:2017 (BSN, 2017). The design of earthquake for the excavation and filling slopes are set based on the earthquake hazard source map with a $10 \%$ probability of exceedance in 50 years provided by the National Earthquake Center (2017). The design of an earthquake is equivalent to a 500-year return period. The horizontal seismic coefficient $(K h)$ was set at 0.5 of the horizontal peak acceleration with the determination of the site class and the amplification factor. The 2017 earthquake hazard source maps produced by the National Earthquake Center showed the research site is located in the zone of Peak Ground Acceleration (PGA) of $0.05-0.1 \mathrm{~g}$. Therefore a median of $0.075 \mathrm{~g}$ was taken. The site class in this research was located in the bedrock (SB) following site classification proposed by the American Association of State Highway and Transportation (AASHTO) (2012). The site class was used as the basis for determining the amplification factor related to the acceleration in the bedrock $\left(F_{g p a}\right)$. The horizontal seismic coefficient that works on the slope mass $(K h)$ following the SNI 8460 is formulated in Equation 2. The allowable safety values required for slope stability are critical SRF $>1.3$ for temporary slope without earthquake load, critical SRF $>1.5$ for permanent slope without earthquake load, and critical SRF $>1.1$ for the slope with earthquake loads.

$$
K h=0.5 \times F_{p g a} \times P G A
$$

where $K h=$ horizontal seismic coefficient; $P G A=$ peak ground acceleration; $F_{p g a}=$ amplification factor.

\section{Results AND Discussion}

\subsection{Rock mass quality and material proper- ties}

The rock mass quality determination from the rock cores indicated that the inlet portal slope consisted of four types of materials: residual soil, fair quality basalt lava, good quality basalt lava, and very good quality basalt lava, as shown in Table 1. Meanwhile, the outlet portal slope consisted of three types of materials: residual soil, good quality basalt lava, and very good quality basalt lava, as shown in Table 2 . The material properties used in the slope stability analyses can be seen in Table 3 .

The failure criterion used for soil material modeling was the Mohr-Coulomb with key parameters of internal friction angle $(\phi)$ and cohesion $(c)$. For soil material obtained from a direct shear test with the results as seen in Table 3. Meanwhile, Generalized Hoek - Brown parameters were gained from triaxial test results, which were then processed using rocdata v.4 software, developed by Rocscience Inc. (2013). The parameter results for the Generalized Hoek-Brown failure criterion can be seen in Table 4.

\subsection{Earthquake}

Load The earthquake hazard source map with a $10 \%$ probability of exceedance in 50 years provided by the National Earthquake Center (2017) showed that the PGA value at the research area was $0.075 \mathrm{~g}$. Based on the Standard Penetration Test (SPT) data, the research area was classified as bedrock (SB) and, therefore, had an amplification factor of 1 . The horizontal seismic coefficient $(K h)$ calculated using Equation 2 was $0.0375 \mathrm{~g}$. This seismic coefficient value was used as an input parameter of the earthquake load in the slope stability analyses.

\subsection{Slope stability}

The slope stability analyses were carried out to determine the slope safety factor due to diversion tunnel excavation. The Portal slope at the inlet section in the tunnel was a temporary structure that served as a water diversion method when the dam is constructed and closed as the dam construction is completed. In contrast, the portal at the outlet section func- 
TABLE 1 . The calculation of rock mass quality value by using GSI at inlet portal slope.

\begin{tabular}{clcccl}
\hline Depth $(\mathrm{m})$ & $\begin{array}{l}\text { Lithology / } \\
\text { Weathering degree }\end{array}$ & $\begin{array}{c}\text { Average joint } \\
\text { condition }\end{array}$ & $R Q D$ & GSI $^{*}$ & Rock mass quality (GSI) \\
\hline $0.0-6.0$ & Residual Soil & 0 & 0 & 0 & Very poor \\
$6.0-10.0$ & Basalt lava / SW & 18.75 & 41 & 49 & Fair \\
$10.0-20.0$ & Basalt lava / SW & 25.00 & 65 & 70 & Good \\
$20.0-25.0$ & Basalt lava / SW & 25.00 & 85 & 80 & Very good \\
$25.0-41.0$ & Basalt lava / SW & 21.25 & 71 & 67 & Baik \\
$41.0-45.0$ & Basalt lava / SW & 25.00 & 83 & 79 & Very good \\
\hline
\end{tabular}

Note: *)GSI = 1.5JCond $+R M R / 2 ; \mathrm{SW}=$ slightly weathered; $R Q D=$ rock quality designation; joint conditions of rock cores as described in Bieniawski (1989)

TABLE 2 . The calculation of rock mass quality value by using GSI at outlet portal slope.

\begin{tabular}{clcccl}
\hline Depth $(\mathrm{m})$ & $\begin{array}{l}\text { Lithology / } \\
\text { Weathering degree }\end{array}$ & $\begin{array}{c}\text { Average joint } \\
\text { condition }\end{array}$ & RQD & GSI $^{*}$ & Rock mass quality (GSI) \\
\hline $0.0-1.0$ & Reidual Soil & 0 & 0 & 0 & Very poor \\
$1.0-15.0$ & Basalt lava / SW & 23.92 & 46 & 59 & Good \\
$15.0-21.0$ & Basalt lava / SW & 25.00 & 80 & 78 & Very Good \\
$21.0-53.0$ & Basalt lava / SW & 24.06 & 59 & 65 & Good \\
$54.0-60.0$ & Basalt lava / SW & 25.00 & 81 & 78 & Very good \\
\hline
\end{tabular}

Note: *)GSI = 1.5JCond $+R M R / 2 ; \mathrm{SW}=$ slightly weathered; $\mathrm{RQD}=$ rock quality designation; joint conditions of rock cores as described in Bieniawski (1989)

TABLE 3. Material properties of rock cores.

\begin{tabular}{|c|c|c|c|c|c|c|c|c|c|c|}
\hline \multirow{2}{*}{ No } & \multirow{2}{*}{ Borehole } & \multirow{2}{*}{$\begin{array}{c}\text { Layer / } \\
\text { Depth }\end{array}$} & \multirow{2}{*}{ Lithology } & $\gamma_{\text {bulk }}$ & $\gamma_{\text {sat }}$ & $E$ & $v$ & $\sigma c$ & c & $\phi$ \\
\hline & & & & $\mathrm{MN} / \mathrm{m}^{3}$ & $\mathrm{MN} / \mathrm{m}^{3}$ & $\mathrm{MPa}$ & & $\mathrm{MPa}$ & $\mathrm{MPa}$ & $\circ$ \\
\hline \multirow{6}{*}{1} & \multirow{6}{*}{$\begin{array}{l}\text { BT.02 (near } \\
\text { tunnel } \\
\text { inlet) }\end{array}$} & $0-6$ & Residual Soil & 0.0127 & 0.0168 & 13.00 & 0.30 & & 0.04 & 8.11 \\
\hline & & $6-10$ & Basalt lava & 0.0232 & 0.0235 & 4844.56 & 0.11 & 32.45 & & \\
\hline & & $10-20$ & Basalt lava & 0.0232 & 0.0235 & 4844.56 & 0.11 & 32.45 & & \\
\hline & & $20-25$ & Basalt lava & 0.0227 & 0.0236 & 12573.00 & 0.09 & 29.56 & 4.72 & 23.47 \\
\hline & & $25-41$ & Basalt lava & 0.0232 & 0.0235 & 4746.49 & 0.11 & 32.63 & & \\
\hline & & $41-$ & Basalt lava & 0.0227 & 0.0236 & 26200.00 & 0.09 & 44.78 & & \\
\hline \multirow{5}{*}{2} & \multirow{5}{*}{$\begin{array}{l}\text { B.AD.5 } \\
\text { (near } \\
\text { tunnel } \\
\text { outlet) }\end{array}$} & $0-1$ & Residual Soil & 0.0104 & 0.0151 & 13.00 & 0.30 & & 0.04 & 4.38 \\
\hline & & $1-15$ & Basalt lava & 0.0243 & 0.0249 & 6894.18 & 0.11 & 34.40 & 7.62 & 35.45 \\
\hline & & $15-21$ & Basalt lava & 0.0233 & 0.0241 & 5776.21 & 0.10 & 30.01 & & \\
\hline & & & Basalt lava & 0.0243 & 0.0249 & 6894.18 & 0.11 & 34.40 & & \\
\hline & & & Basalt lava & 0.0233 & 0.0241 & 5776.21 & 0.10 & 30.01 & & \\
\hline
\end{tabular}

Note: $\gamma_{\text {bulk }}=$ bulk unit weight; $\gamma_{\text {sat }}=$ saturated unit weight; $E=$ Young's modulus; $v=$ Poisson's ratio; $\sigma \mathcal{C}=$ uniaxial compressive strength (UCS) of intact rock; $c=$ cohesion; $\phi=$ internal friction angle. 
Numerical Analysis of Slope Stability Due to Excavation of Diversion TunNel

TABLE 4. Generalized Hoek-Brown parameters for material modeling.

\begin{tabular}{|c|c|c|c|c|c|c|c|c|c|c|}
\hline \multirow{2}{*}{ No } & \multirow{2}{*}{$\begin{array}{l}\text { Bor ID / } \\
\text { Section }\end{array}$} & \multirow{2}{*}{$\begin{array}{l}\text { Layer / } \\
\text { Depth }\end{array}$} & \multirow{2}{*}{ Lithology } & \multirow{2}{*}{ GSI } & \multirow{2}{*}{$\begin{array}{l}\text { Rock mass } \\
\text { quality }\end{array}$} & $m_{i}$ & $m_{b}$ & $s$ & $a$ & $E_{\mathrm{rm}}$ \\
\hline & & & & & & & $\mathrm{MPa}$ & $\mathrm{MPa}$ & Mpa & $\mathrm{MPa}$ \\
\hline \multirow{6}{*}{1} & \multirow{6}{*}{$\begin{array}{l}\text { BT.02 / } \\
\text { Inlet } \\
\text { Section }\end{array}$} & $0-6$ & Residual Soil & 0 & Very poor & & & & & \\
\hline & & & Basalt lava & 49 & Fair & 7.089 & 0.4247 & 0.0006 & 0.5061 & 487.6 \\
\hline & & $10-20$ & Basalt lava & 70 & Good & 7.089 & 1.3637 & 0.0129 & 0.5014 & 1635.6 \\
\hline & & $20-25$ & Basalt lava & 80 & Very Good & 7.863 & 2.6659 & 0.0551 & 0.5006 & 6000.1 \\
\hline & & $25-41$ & Basalt lava & 67 & Good & 7.089 & 1.3637 & 0.0129 & 0.5014 & 1635.6 \\
\hline & & $41-45$ & Basalt lava & 79 & Very Good & 7.863 & 2.6659 & 0.0551 & 0.5006 & 6000.1 \\
\hline \multirow{4}{*}{2} & B.AD.5 / & & $\begin{array}{l}\text { Residual Soil } \\
\text { Basalt lava }\end{array}$ & $\begin{array}{c}0 \\
59\end{array}$ & $\begin{array}{l}\text { Very poor } \\
\text { Good }\end{array}$ & 7.089 & 0.7358 & 0.0026 & 0.5031 & 1303.4 \\
\hline & Outlet & & Basalt lava & 78 & Very Good & 7.863 & 2.3467 & 0.0412 & 0.5007 & 2609.1 \\
\hline & Section & & & 65 & Good & 7.089 & 0.7358 & 0.0026 & 0.5031 & 1303.4 \\
\hline & & $54-60$ & Basalt lava & 78 & Very Good & 7.863 & 2.3467 & 0.0412 & 0.5007 & 2609.1 \\
\hline
\end{tabular}

Note: $G S I=$ Geological strength index; $m_{i}=$ intact rock constant; $m_{b}, s$, and $a=$ rock mass material constants; $E_{\mathrm{rm}}=$ Rockmass young's modulus

tioned as a part of the outlet section of the intake structure. The slope inclination design was $45^{\circ}$ with a ratio of $1 \mathrm{~V}: 1 \mathrm{H}$, a vertical height of 5 $\mathrm{m}$, and a bench of $2 \mathrm{~m}$ in length. The geometry of the inlet slope can be seen in Figure 4.

The analysis result of slope stability due to the effect of tunnel excavation without earthquake load at the Y1 inlet section area had a critical SRF value of 2.35 in a condition before the tunnel excavation (Figure 5) and a critical SRF value of 2.34 after the tunnel excavation (Figure 6). Using the same analysis, the Y2 outlet section had a critical SRF value of 13.27 in a condition before tunnel excavation and a critical SRF value of 5.55 after the tunnel excavation.

With an added earthquake load at the Y1 inlet section had a critical SRF value of 2.05 both before and after the tunnel excavation, the Y2 outlet section showed a critical SRF value of 11.49 before the tunnel excavation (Figure 5) and a critical SRF value of 5.54 after the tunnel excavation (Figure 7). In general, the decreasing percentage of critical SRF without earthquake load is more significant than if calculated with earthquake load because the slope condition analysis at the static load resulted in a relatively bigger critical SRF compared to analysis with earthquake load.

At the Y1 inlet section, the tunnel excavation did not have a significant effect on slope stability. This condition was influenced by the location of the tunnels, which is located in good quality of basalt lava, stated by the value of Rockmass Elastic Modulus (Erm) of 1635.60
Mpa overburden above consisted of very good quality basalt lava with Erm value of 6000.1 $\mathrm{MPa}$. The analysis results showed that the maximum shear strain value was located on the slope of the tunnel portal, both before and after excavation, which was dominated by residual soil.

At the Y2 outlet section, the tunnel excavation had a more significant effect on the slope stability. This condition was influenced by the location of the tunnels, which is located between good quality and very good quality of basalt lava with Erm values of 1303,4 MPa and $2609,1 \mathrm{MPa}$. However, compared to the inlet area, the Erm value at the outlet area was not as good as the inlet area. The analysis results showed that the maximum shear strain value was located on the slope of the tunnel portal before the tunnel excavation. After the tunnel being excavated, the maximum shear strength is concentrated at the tunnel area.

However, the analysis result for all parts of the slope at the inlet and outlet areas showed a safe condition under the provision required by SNI 8460:2017 (BSN, 2017). The modeling result of slope stability due to tunnel excavation at the inlet and outlet sections, both with or without earthquake load, can be seen in Table 5 .

\section{CONCLUSION}

The results of rock cores analysis using the GSI method showed that the inlet tunnel slope consisted of four types of materials: residual soil, fair quality of basalt lava, good quality 

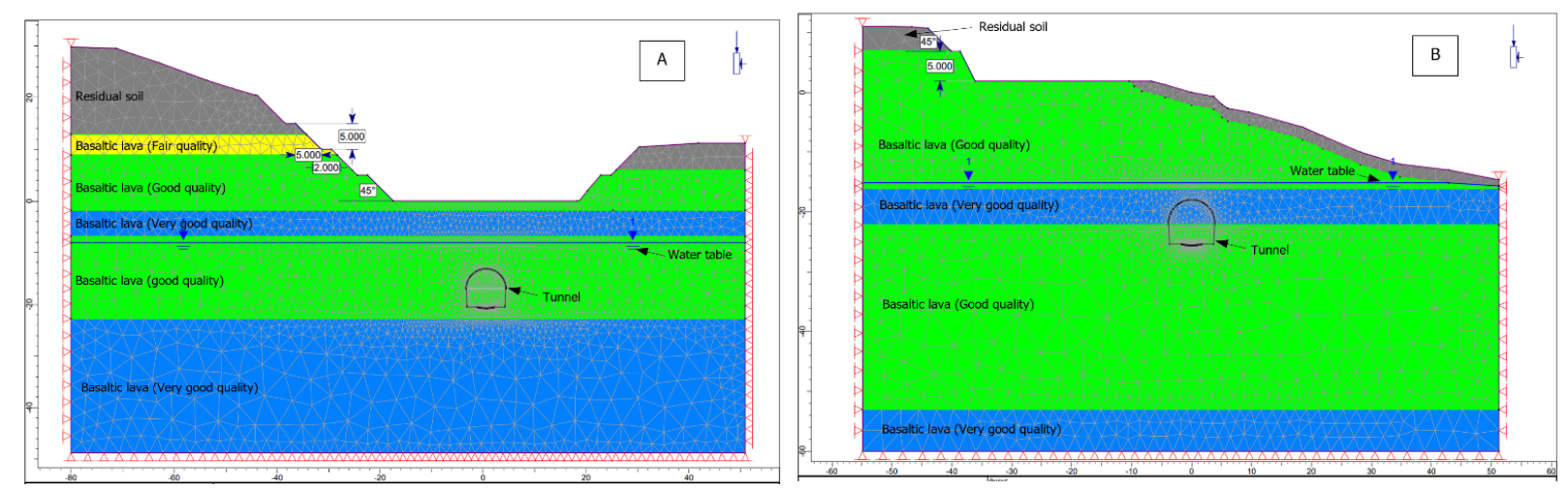

FIGURE 4. Slope geometry of Y1 inlet section and Y2 outlet section area: (A) Inlet; (B) Outlet.

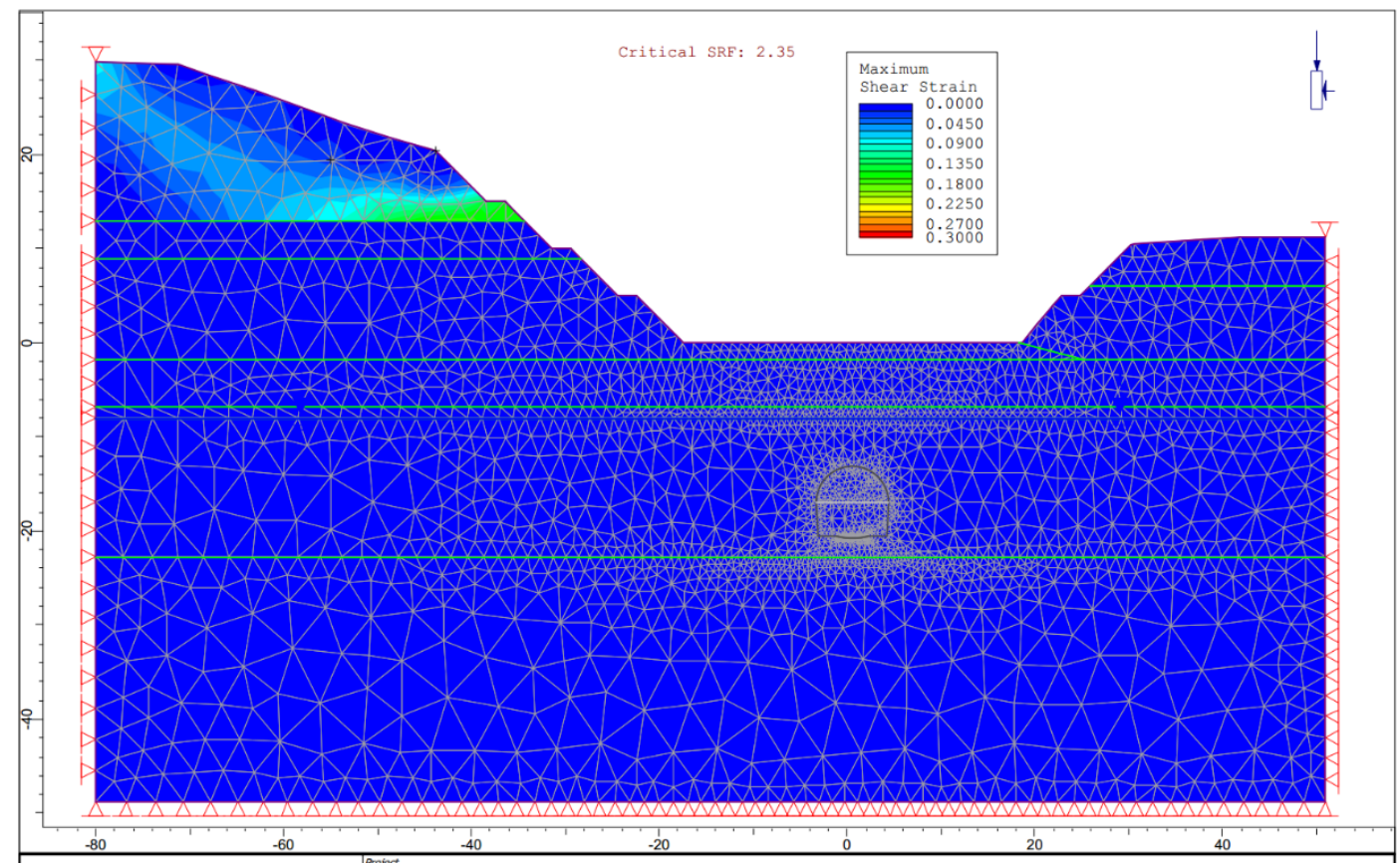

FIGURE 5. The analysis result of the Y1-Y1 inlet section area before the tunnel excavation.

TABLE 5. The analysis result of tunnel stability due to the effect of tunnel excavation.

\begin{tabular}{|c|c|c|c|c|c|c|}
\hline \multirow{2}{*}{ No } & \multirow{2}{*}{ Location / Section } & \multirow{2}{*}{ Slope condition } & \multicolumn{2}{|c|}{ Critical SRF } & \multirow{2}{*}{$\begin{array}{l}\text { Allowable } \\
\text { SRF }\end{array}$} & \multirow{2}{*}{$\begin{array}{l}\text { The effect of } \\
\text { excavation } \\
\text { on SRF (\%) }\end{array}$} \\
\hline & & & $\begin{array}{c}\text { Before } \\
\text { excavation }\end{array}$ & $\begin{array}{c}\text { After } \\
\text { excavation }\end{array}$ & & \\
\hline \multirow{2}{*}{1} & Inlet Section Y 1 & Static load & 2.35 & 2.34 & 1.3 & -0.43 \\
\hline & Inlet Section Y 1 & earthquake load & 2.05 & 2.05 & 1.1 & 0.00 \\
\hline \multirow{2}{*}{2} & Outlet Section Y 2 & static load & 13.27 & 5.55 & 1.5 & -58.18 \\
\hline & Outlet Section Y 2 & earthquake load & 11.49 & 5.54 & 1.1 & -51.78 \\
\hline
\end{tabular}

Note: $\mathrm{SRF}=$ Strength reduction factor 
Numerical Analysis of Slope Stability Due to Excavation of Diversion TunNel

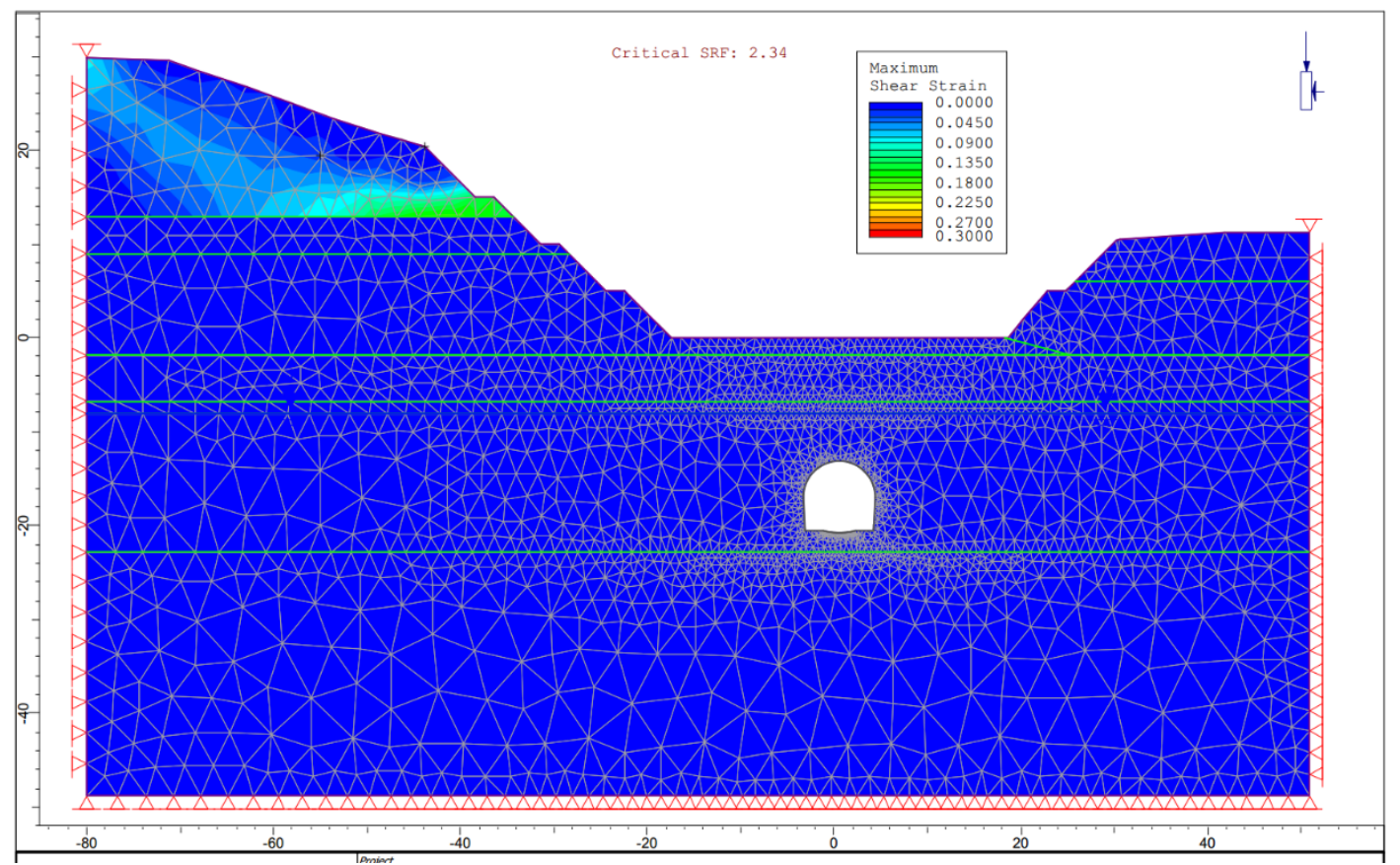

FIGURE 6. The analysis result of the inlet Y1-Y1 section area after the tunnel excavation.

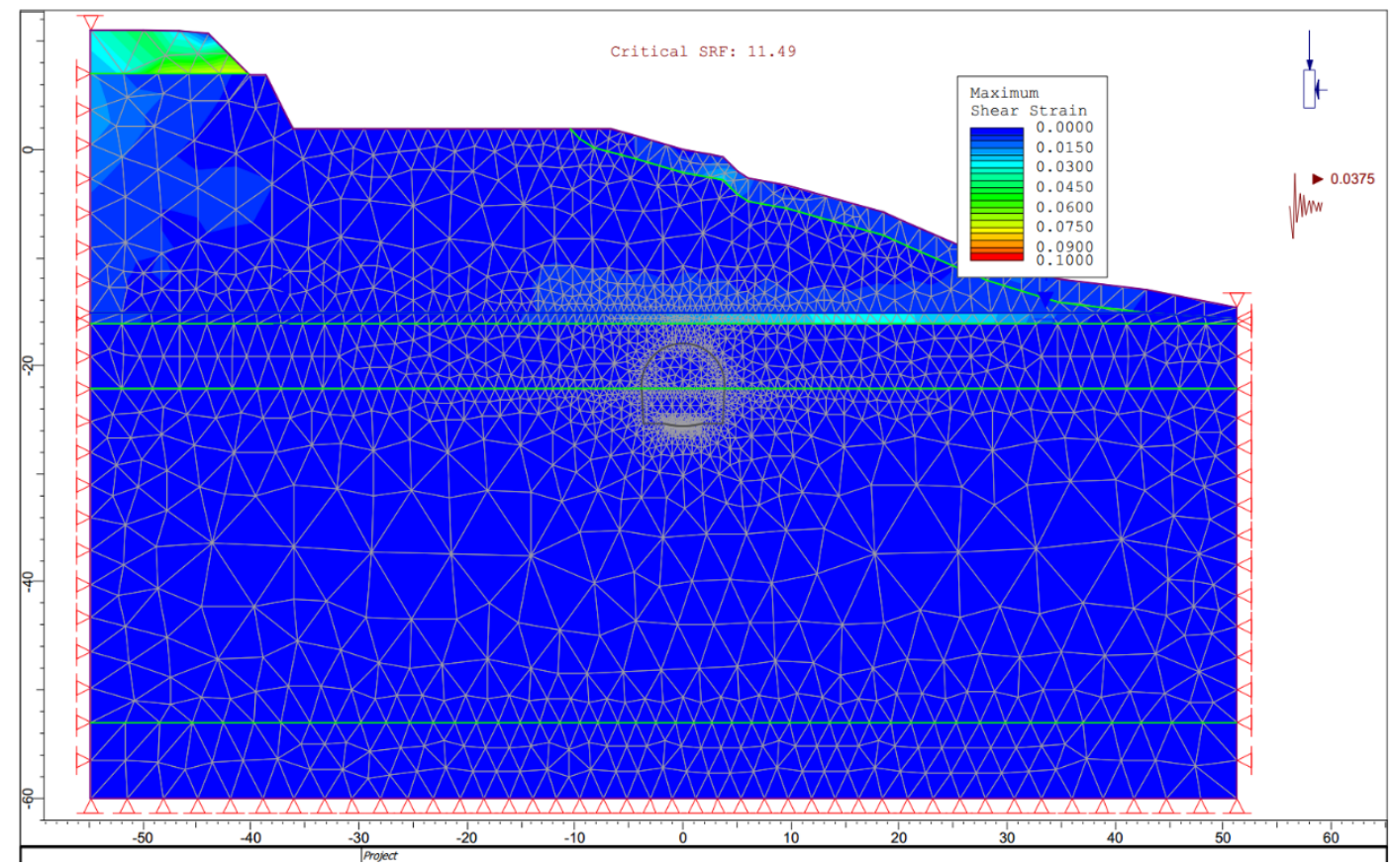

FIGURE 7. The analysis result of the Y2-Y2 outlet section area before the tunnel excavation (earthquake load applied). 


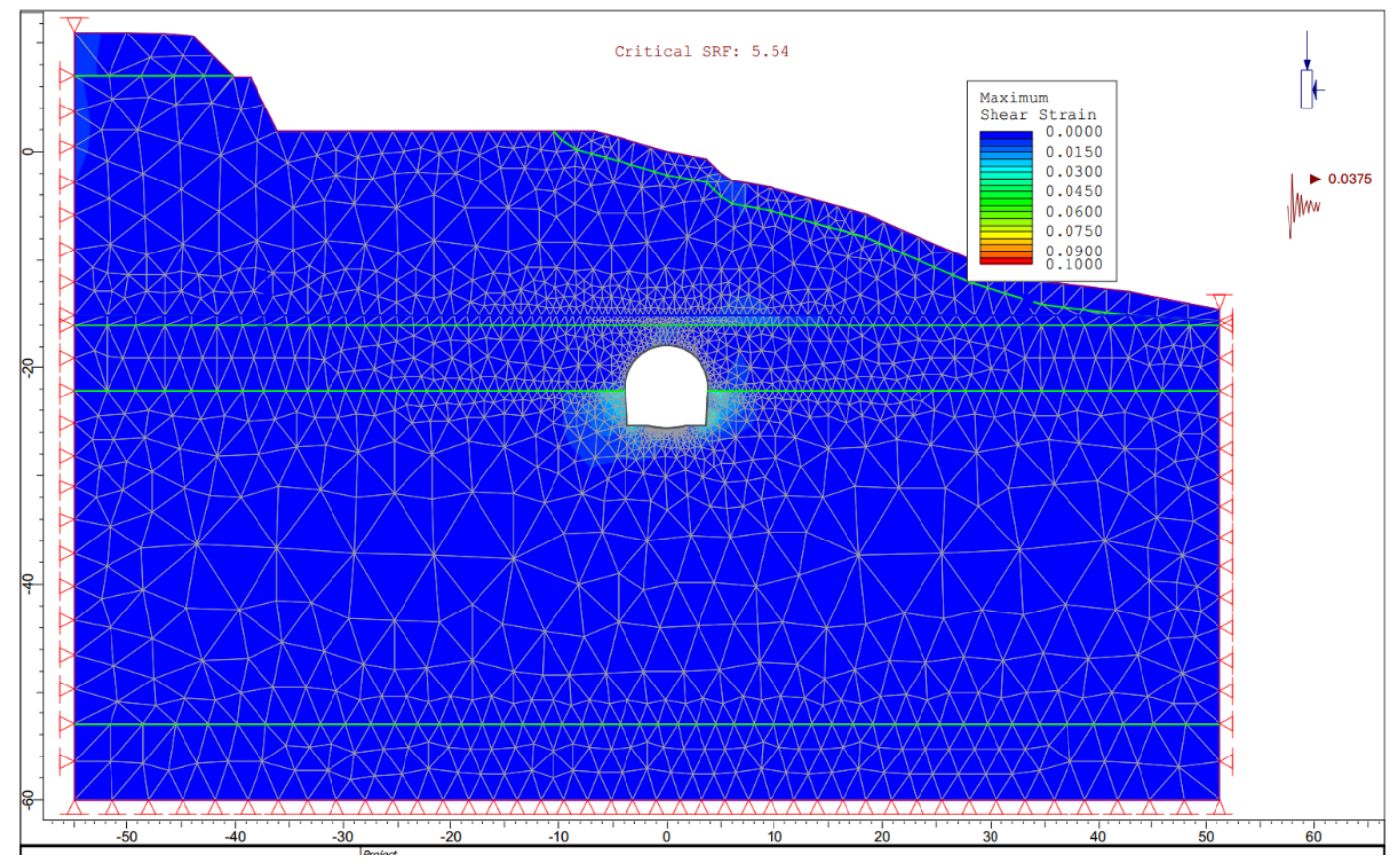

FIGURE 8. The analysis result of the Y2-Y2 outlet section area after the tunnel excavation (earthquake load applied).

of basalt lava, and very good quality of basalt lava. Meanwhile, the outlet portal slope consisted of three types of materials: residual soil, good quality basalt lava, and very good quality basalt lava. The calculated horizontal seismic coefficient for the pseudo-static slope stability analysis was 0.0375 . The stability analyses of tunnel inlet and outlet slopes showed that all were above the allowable safety factor values. At the Y1 inlet section, the tunnel excavation did not have a significant effect on slope stability. It was demonstrated by an extremely small decrease in a critical SRF value of $0.43 \%$ for a condition without an earthquake load and an unchanged critical SRF value in a condition with an earthquake load. At the Y2 outlet section, the tunnel excavation had a more significant effect on the slope stability. It was exhibited by the decrease in the critical SRF value of $58.18 \%$ in the static condition and a decrease in the critical SRF value of $51.78 \%$ in the condition of earthquake load application.

\section{ACKNOWLEDGEMENTS}

The authors would like to express their gratitude to Balai Besar Wilayah Sungai Pompengan Jeneberang, the Directorate General of Water Resources, the Ministry of Public Works, and Housing of Indonesia. The first author also would like to thank the Ministry of Public Works and Housing of Indonesia for the master's degree scholarship. The assistance of Mr. Bernardus Anggit Winahyu in conducting field and laboratory works is gratefully acknowledged.

\section{REFERENCES}

AASHTO. (2012). Aashto LRFD Bridge Design Specifications. Washington, DC: the American Association of State Highway and Transportation. BBWS Pompengan-Jeneberang. (2016). Sertifikasi Desain Bendungan Pamukkulu. Makassar.

Bieniawsky, Z. T. (1989). Engineering Rock Mass Classification Mining and Mineral Resources Research Institute. Pennsylvania State University.

BSN (2017). SNI 8460:2017. Persyaratan Perancangan Geoteknik. Jakarta.

Hammah, R.E; Curran J.H; Yacoub T; Corkum B. (2004). Stability Analysis of Rock Slopes using the Finite Element Method. EUROCK 2004 \& 53rd Geomechanics Colloquium. Schubert (ed.).

Hoek, E., Carter, T., \& Diederichs, M. (2013). Quantification of the Geological Strength Index Chart. US Rock Mechanics /Geomechanics Symposium. San Francisco: June 23-26, 2013.

National Earthquake Research Centre. (2017). Peta Sumber dan Bahaya Gempa Indonesia. Jakarta: Kementerian Pekerjaan Umum dan Perumahan Rakyat.

Nugroho, W. (2020). Evaluasi Kondisi Geologi Teknik dan Analisis Kestabilan Terowongan Pen- 
Numerical Analysis of Slope Stability Due to ExcaVation of Diversion TunNel

gelak Bendungan Pamukkulu Provinsi Sulawesi Selatan. Master of Engineering Thesis. Department of Geological Engineering, Faculty of Engineering, Universitas Gadjah Mada, Yogyakarta: Unpublished.

Sivakugan, N; Shukla, S.K; Das, B.M. (2013). Rocks
Mechanics an Introduction. New York: CRC Press.

Sukamto, R., \& Supriatna, S. (1982). Peta Geologi Lembar Ujungpandang, Benteng dan Sinjai, Sulawesi. Bandung: Pusat Pengembangan dan Penelitian Geologi. 